PAEDAGOGIA ChRISTIANA

I/21 (2008) - ISSN 1505-6872

Matgorzata Perechowska*

Włocławek

\title{
Problemy rodzin dzieci niepełnosprawnych intelektualnie
}

Rozpoznanie u dziecka niepełnosprawności intelektualnej stawia rodziców w zupełnie nowej, nieoczekiwanej sytuacji życiowej, dotyczącej każdej płaszczyzny ich życia. Rodzice z reguły nie są przygotowani do podjęcia zadań wynikających z posiadania dziecka $\mathrm{z}$ upośledzeniem umysłowym. Bycie rodzicem dziecka niepełnosprawnego intelektualnie nie jest sprawą ani prosta, ani łatwą. Nie ma chyba problemów i uczuć, z którymi nie musieliby się borykać czy przeżywać rodzice tych dzieci.

Halina Borzyszkowska określa je jako rodziny z „niezawinionym nieszczęściem”, którym należy się głęboki szacunek za przyjęcie niepełnosprawnego dziecka i trud jego wychowania ${ }^{1}$. Opisując najogólniej przeżycia rodziców, zauważa się, że przechodzą oni stopniowo ewolucję od pytania „Dlaczego właśnie nas i nasze dziecko dotknęło to nieszczęście?” do pytania „Co i jak możemy zrobić, aby pomóc naszemu dziecku?”2. Droga do zaakceptowania niepełnosprawności umysłowej swojego dziecka i siebie w roli jego rodzica jest bardzo długa, trudna i skomplikowana, a dojście do pełnej akceptacji czasami okazuje się niemożliwe.

\section{Macierzyństwo}

Naturalne jest, że rodzice oczekują, iż dziecko urodzi się zdrowe i wiążą $\mathrm{z}$ nim swoje nadzieje. Jeszcze przed narodzeniem dziecka pojawia się u kobiet

${ }^{*}$ S. dr Małgorzata Perechowska ZSNM, wykładowca w Studium Teologii we Włocławku, katechetka w Gimnazjum nr 2 im. Ks. J. Popiełuszki we Włocławku.

${ }^{1}$ H. Borzyszkowska, Izolacja społeczna rodzin majacych dziecko upośledzone umysłowo w stopniu lekkim, Gdańsk 1997, s. 10.

${ }^{2}$ A. Twardowski, Sytuacja rodzin dzieci niepetnosprawnych, w: I. Obuchowska (red.), Dziecko niepetnosprawne w rodzinie, Warszawa 1995, s. 21. 
lęk przed macierzyństwem. Ten typ lęku pojawia się też u kobiet mających zdrowe dzieci. Lęk przed nienormalnością dziecka jest zasadniczym motywem podjęcia badań prenatalnych, zarówno gdy zachodzą realne zagrożenia dla jego rozwoju, wynikające z przyczyn zdrowotnych, jak też zagrożenia wynikające z urojeń i tzw. złych przeczuć3.

Większość kobiet w czasie porodu nie myśli o dziecku, ale o sobie i o swoim bólu. Inaczej jest już bezpośrednio po porodzie, kiedy pojawia się u kobiet lęk związany z przeczuciem złego stanu zdrowia dziecka. Kobiety wnioskują często o zagrożeniu życia dziecka $\mathrm{z}$ zachowania personelu medycznego i z braku kontaktu fizycznego z dzieckiem. W niektórych przypadkach bezpośredni stan zdrowia dziecka po urodzeniu nie wskazuje na patologię rozwoju. Niekiedy po kilku miesiącach czy latach, bądź też po przebytej chorobie dziecka, matki zauważaja, że rozwija się ono wolniej niż jego rówieśnicy. Towarzyszy im wówczas lęk związany z rozpoznaniem upośledzenia umysłowego. Przeżyciem traumatycznym dla rodziców jest zawsze przekazana przez lekarzy informacja o upośledzeniu umysłowym dziecka ${ }^{4}$.

\section{Okresy przeżyć rodziców}

W przeżyciach rodziców po wykryciu upośledzenia u dziecka wyróżnia się w ujęciu modelowym kilka okresów: szoku, kryzysu emocjonalnego, pozornego przystosowania się do sytuacji oraz konstruktywnego przystosowania się do sytuacji ${ }^{5}$. Kiedy rodzice dowiadują się, że ich dziecko będzie upośledzone umysłowo, doznają szoku, zwanego też okresem krytycznym lub okresem wstrząsu emocjonalnego. Większość rodziców załamuje się. Jest to okres bezgranicznego bólu, poczucia krzywdy, beznadziejności, bezradności i poczucia, że ta sytuacja jest bez wyjścia. Występują wówczas u rodziców niekontrolowane reakcje emocjonalne i stany nerwicowe, które wpływają negatywnie nie tylko na stosunek rodziców do siebie, ale i do dziecka. Pojawiają się kłótnie, wrogość i agresja. Rodzice nie wiedza, jak postępować z dzieckiem6.

W opinii społecznej upośledzenie umysłowe jest złem, którego boją się ludzie. Rodzice mają poczucie lęku przed wrogością otoczenia. Boją się poinformować o stanie zdrowia dziecka najbliższą rodzinę, a także przyjaciół i znajomych. Doświadczają niekiedy tak silnego lęku, że unikają znajomych i nie pokazują się z dzieckiem w miejscach publicznych. Źródło tak dużego lęku rodziców zazwyczaj tkwi nie tyle w objawach społecznej wrogości, ale raczej wypływa ze

${ }^{3}$ M. Kościelska, Oblicza upośledzenia, Warszawa 1998, s. 43-44.

${ }^{4}$ E. Clemens, Eltern und die Umweltreaktionen auf die Geburt ienes geistigbehinderten Kindes, w: H. Bach (red.), Familien mit geistig behinderten Kindern, Berlin 1979, s. 20.

${ }^{5}$ Podaję za: A. Twardowski, dz. cyt., s. 21.

${ }^{6}$ Tamże, s. 22. 
zgeneralizowanego złego doświadczenia, wyniesionego na przykład ze szpitala, bądź tkwi w specyficznym sposobie widzenia siebie i dziecka w relacjach $\mathrm{z}$ innymi ludźmi. Aby odczuwać bardzo głęboki lęk przed kontaktami z ludźmi, dlatego że jest się rodzicem dziecka $\mathrm{z}$ upośledzeniem umysłowym, to jak zauważa Małgorzata Kościelska, trzeba samo dziecko traktować jako zło, albo siebie, jako rodzica, widzieć złego, i z tego powodu bać się społecznego potępienia ${ }^{7}$.

Po okresie szoku następuje okres kryzysu emocjonalnego, zwany też okresem rozpaczy lub depresji ${ }^{8}$. Rodzice nie mogą pogodzić się z faktem, że posiadają niepełnosprawne dziecko. Przeżywają nadal silne negatywne emocje, ale już nie tak burzliwie, jak w pierwszym okresie. Są przygnębieni, zrozpaczeni i bezradni. Mają poczucie zawodu wynikające $\mathrm{z}$ rozbieżności między wymarzonym a rzeczywistym obrazem dziecka. Często też mają poczucie winy, że to z ich powodu dziecko jest niepełnosprawne intelektualnie. Pesymistycznie też oceniają przyszłość dziecka. Konflikty i kłótnie między rodzicami doprowadzają niekiedy do zjawiska odsuwania się ojca od rodziny. Może to być niekiedy niezajmowanie się sprawami rodzinnymi, ucieczka w pracę zawodową, bądź też może prowadzić do opuszczenia rodziny. Zakłócone relacje między rodzicami w istotny sposób wpływają na psychikę niepełnosprawnego dziecka9 .

Kolejnym etapem w przeżyciach rodziców jest stadium pozornego przystosowania się do sytuacji. Rodzice nie mogąc pogodzić się z faktem, że ich dziecko jest $\mathrm{z}$ upośledzeniem umysłowym, wytwarzają sobie jego nieprawidłowy obraz. Często usiłują zaprzeczyć diagnozie i poszukują specjalistów, którzy by jej nie potwierdzili ${ }^{10}$. Są oni przeświadczeni, że diagnoza jest mylna, a przynajmniej nie ostateczna. Nieuznawanie faktu niepełnosprawności dziecka jest mechanizmem obronnym rodziców. Wielu zaś rodziców pogodzonych z tym faktem stosuje często mechanizm obronny, jakim jest nieuzasadniona wiara w możliwość wyleczenia dziecka. Podejmują oni żmudne i kosztowne wysiłki, poszukując coraz to nowych specjalistów i cudownych leków, które uzdrowiłyby ich dziecko ${ }^{11}$. Innym mechanizmem obronnym jest poszukiwanie winnych niepełnosprawności dziecka. Rodzice oskarżają lekarzy o błędy lub zaniedbania w okresie ciąży, porodu czy leczenia dziecka. Zdarza się, że rodzice siebie obarczają wina, zarzucając sobie na przykład zaburzenia genetyczne bądź też brak dostatecznej opieki. W końcu winę przenoszą na los, na Pana Boga, traktując to jako karę za swoje wcześniejsze postępowanie, jako karę za grzechy ${ }^{12}$. A nawet jeśli wiedza, że ułomność ich dziecka pochodzi z innej przyczyny, to i tak są bardzo wrażliwi na to, co ludzie o tym powiedzą. Sami muszą się zmierzyć z tym problemem

\footnotetext{
${ }^{7}$ M. Kościelska, dz. cyt., s. 48.

${ }^{8}$ A. Twardowski, dz. cyt., s. 22.

${ }^{9}$ Tamże, s. 22-23.

${ }^{10}$ M. Kościelska, dz. cyt., s. 48-49.

${ }^{11}$ A. Twardowski, dz. cyt., s. 24.

${ }^{12}$ Tamże, s. 25.
} 
i szukać sensu cierpienia ${ }^{13}$. Okres pozornego przystosowania może trwać bardzo długo. Kończy się on pogodzeniem rodziców z faktem, że już nic nie mogą zrobić dla swojego dziecka. Zawiedzione nadzieje przenoszą na dziecko pełnosprawne intelektualnie.

Występuje jeszcze okres konstruktywnego przystosowania się rodziców do sytuacji ${ }^{14}$. Jego istotą jest przeżywanie przez rodziców problemu, czy i jak moga dziecku pomóc. Próbują racjonalnie rozpatrzyć swoją sytuację rodzinną. Zaczynają stosować różne zabiegi wychowawcze i rehabilitacyjne. Całe ich życie rodzinne skupia się wokół wspólnego celu, jakim jest niesienie pomocy dziecku niepełnosprawnemu. Kontakty z dzieckiem zaczynają przynosić im satysfakcję, dostrzegają postępy dziecka i przeżywają z tego powodu radość. W przeżyciach rodziców zaczynają w tym okresie dominować uczucia pozytywne.

W przedstawionym ujęciu modelowym przeżyć rodziców, poszczególne okresy w przypadkach konkretnych rodzin, mogą trwać dłużej lub krócej i mogą być mniej lub bardziej intensywnie przeżywane. Często rodzice nie dochodzą do okresu konstruktywnego przystosowania się, pozostając w rozpaczy i poczuciu beznadziejności, że już nic się nie da zrobić. Jedynie rodzice osiagający ostatni okres potrafią naprawdę pomóc swojemu dziecku.

Istotne znaczenie ma tu odporność emocjonalna i sposób reagowania na stresy. Rodzice aktywnie zaangażowani i dążący do konstruktywnego rozwiązania, znajdują się w korzystniejszej sytuacji niż rodzice reagujący lękiem i wycofaniem $^{15}$.

Istnieje też zjawisko izolacji społecznej rodzin dzieci z upośledzeniem umysłowym. O izolacji można mówić w dwóch aspektach, a mianowicie jako o izolacji zewnętrznej i wewnętrznej. Izolacja zewnętrzna występuje wtedy, gdy rodzice czują się odsunięci przez środowisko. Izolacja wewnętrzna ma miejsce wówczas, gdy rodzina sama zamyka się przed wpływem środowiska społecznego ${ }^{16}$. Jedną z głównych przyczyn izolowania się rodzin mogą być negatywne reakcje otoczenia na fakt posiadania dziecka z upośledzeniem umysłowym, ale i chęć uniknięcia przykrości. Izolacja społeczna może także wynikać z braku jakichkolwiek kontaktów i doświadczeń społeczeństwa z osobami niepełnosprawnymi intelektualnie ${ }^{17}$. Wiedza społeczeństwa o problemach życiowych tych osób jest powierzchowna i ksztaltowana przez stereotypowe opinie.

Trudnym problemem są negatywne postawy społeczne, stygmatyzacja dziecka przez rówieśników bądź też izolacja. Stanisław Kowalik, przedstawiając koncepcję społecznego kontekstu upośledzenia umysłowego B. Farbera, podkre-

${ }^{13}$ A. Sobolewska, Maski Pana Boga, w: A. Gustavsson i E. Zakrzewska-Manterys (red.), Upośledzenie w społecznym zwierciadle, Warszawa 1997, s. 276.

${ }^{14}$ A. Twardowski, dz. cyt., s. 25-26.

15 Tamże, s. 34.

${ }^{16}$ H. Borzyszkowska, dz. cyt., s. 52

${ }^{17}$ A. Ostrowska, Postawy społeczeństwa polskiego w stosunku do osób niepetnosprawnych, w: A. Gustavsson i E. Zakrzewska-Manterys (red.), dz. cyt., s. 83. 
śla specjalny status społeczny osoby niepełnosprawnej ${ }^{18}$. To ustosunkowanie się członków społeczeństwa do osoby niepełnosprawnej może być dwojakie. Będzie ono uzależnione od etykiety, jaka zostanie przypisana osobie naznaczonej. Może to być etykieta dewianta lub osoby niekompetentnej. Dewiant to osoba jakościowo odmienna od przeciętnych członków społeczeństwa, dysponująca innym systemem wartości, dążąca do nieakceptowanych społecznie celów, postępująca w sposób sprzeczny z obowiązującymi normami. Osoba niekompetentna różni się z kolei tylko stopniem nasilenia cech, które są typowe dla całej populacji. Będzie więc wykazywała mniejsze zdolności do wykonywania normalnych zadań społecznych, będzie się starała przestrzegać norm, ale nie będzie jej to wychodziło ze względu na określone braki intelektualne. Jednak najbardziej istotną różnicą w etykietowaniu kogoś jako dewianta lub osoby niekompetentnej jest stopień koncentracji członków społeczeństwa w procesie naznaczania. Od dewianta oczekuje się zachowania w sposób nienormalny w kontaktach z innymi, zaś od osoby niekompetentnej oczekuje się podejmowania normalnych ról społecznych. Wypływają z tego poważne konsekwencje. Otóż, jeśli osoba upośledzona jest etykietowana jako dewiant, to jej zachowanie nie jest efektem defektu biologicznego, lecz wynikiem oczekiwań i nacisków społecznych. Jest to negatywny skutek procesu naznaczania społecznego. W przypadku osoby niekompetentnej nie ma tak negatywnych skutków ${ }^{19}$.

\section{Edukacja}

Dzieci z upośledzeniem umysłowym wymagają większego zakresu czynności opiekuńczych. Potrzebują pomocy w przemieszczaniu się, jedzeniu, załatwianiu potrzeb fizjologicznych, zabawie czy zajęciach dydaktycznych. Ważnym momentem w życiu dziecka jak i rodziców jest jego pójście do przedszkola publicznego lub specjalnego. Rodzice obawiają się o to, jak ich dziecko zostanie przyjęte przez kolegów i nauczycieli i czy podoła wymaganiom.

Kolejnym etapem jest nauka w szkole. Niektóre dzieci od razu podejmują naukę w szkole specjalnej, inne w szkole publicznej. Trudności w nauce sprawiają, że są one kierowane do poradni pedagogiczno-psychologicznej, gdzie otrzymują orzeczenia o upośledzeniu umysłowym. Mogą one wówczas kontynuować naukę w klasach integracyjnych w szkołach publicznych lub szkołach specjalnych. Jednak niewielki procent dzieci z lekkim upośledzeniem umysłowym korzysta z pełnej integracji. Nieco więcej korzysta z częściowej integracji realizując obowiązek szkolny w oddziałach specjalnych lub poprzez nauczanie indywidualne w szkołach publicznych. Największy procent stanowią uczniowie z lekkim upośledzeniem umysłowym uczęszczający do szkoły podstawowej specjalnej

\footnotetext{
${ }^{18}$ S. Kowalik, Upośledzenie umysłowe. Teoria i praktyka rehabilitacji, Poznań 1989, s. 106.

${ }^{19}$ Tamże, s. 107.
} 
$(76,6 \%)^{20}$. Często rodzice wstydzą się, że ich dzieci uczęszczają do tego typu klas czy szkół.

Dalszą naukę mogą oni kontynuować między innymi w szkołach specjalnych przysposabiających do pracy zawodowej, w zasadniczych szkołach zawodowych specjalnych, szkołach średnich specjalnych czy też w specjalnych ośrodkach szkolno-wychowawczych. Perspektywa zatrudnienia osób z upośledzeniem umysłowym nie jest realna w powszechnym wymiarze. Zastępują ją coraz liczniej powstające warsztaty terapii zajęciowej, które stanowią formę pracy dla osoby niepełnosprawnej intelektualnie ${ }^{21}$. Zapełniają one czas wolny, uczą współżycia w grupie i dają osobom z upośledzeniem umysłowym poczucie, że one też pracują.

\section{Dorastanie}

Okres dorastania dzieci niepełnosprawnych intelektualnie jest czasem licznych rozterek rodziców związanych z dalszym kształceniem dzieci i zdobywaniem przez nie zawodu. Także dorastająca osoba $\mathrm{z}$ upośledzeniem umysłowym może przeżywać liczne problemy i lęki egzystencjalne ${ }^{22}$. Przeżywane przez nią frustracje mogą być przyczyną agresji kierowanej ku rodzicom. O ile pełnosprawni rówieśnicy rozpoczynają pracę zawodową, o tyle osobie niepełnosprawnej nie zawsze udaje się podjąć pracę i wówczas na rodziców spada obowiązek opieki nad nią.

Młodzież niepełnosprawna intelektualnie marzy o założeniu rodziny. Istnieje jednak powszechne przekonanie, że osoby te powinny pozostać samotne. I o ile osoby z lekkim upośledzeniem umysłowym mogą podejmować role małżeńskie i rodzicielskie, o tyle problematyka małżeństw osób z głębokim upośledzeniem umysłowym budzi wiele kontrowersji. Zazwyczaj opiekunowie uzurpują sobie prawo do decydowania za te osoby we wszystkim. Jednoznacznie wypowiada się w tej sprawie Krzysztof Lausch, oponując bardzo stanowczo przeciwko takim małżeństwom. Uzasadnia on to między innymi brakiem, koniecznej do prowadzenia odrębnego gospodarstwa, orientacji w otoczeniu, posiadaniem błędnego obrazu samych siebie oraz swoich realnych możliwości, zaburzeniami w podejmowaniu odpowiednich decyzji i wiążącej się z nimi odpowiedzialności²3.

${ }^{20}$ Podaję za J. Pańczyk, Pedagogika specjalna w Polsce u progu XXI wieku, w: W. Dykcik (red.), Pedagogika specjalna, Poznań 1997, s. 95-96.

${ }^{21}$ J. Lausch-Żuk, Trudne wybory w wychowaniu i rehabilitacji osób z głębsza niepetnosprawnościq umysłowq, w: J. Pańczyk i W. Dykcik (red.), Pedagogika specjalna wobec zagrożeń $i$ wyzwań XXI wieku. Materiały z obrad XVI sekcji II Zjazdu Pedagogicznego w Poznaniu (21-23 wrzesień 1998), Poznań 1999, s. 278.

${ }^{22}$ A. Twardowski, dz. cyt., s. 33.

${ }^{23}$ K. M. Lausch, Teoretyczne podstawy katechizacji osób głębiej upośledzonych umystowo, Warszawa 1987, s. 209-229. 
W Holandii prawo zezwala ludziom z głębszym upośledzeniem umysłowym na zawieranie małżeństwa. W Danii istnieją tak zwane małżeństwa chronione, którym zapewniono odpowiednie warunki do życia i wychowania dzieci, a wykwalifikowany personel sprawuje nad nimi opiekę ${ }^{24}$. Badania przeprowadzone w Niemczech wykazały, że prawie połowa badanych osób z upośledzeniem umysłowym wyraziła chęć zawarcia związku małżeńskiego. Pojecie „ślubu” kojarzyło się im z faktem bycia prawdziwą kobieta lub prawdziwym mężczyzna, z posiadaniem rodziny, z przyjemnością, z miłością, z nadzieją na zmianę sytuacji życiowej i wyprowadzeniem się z ośrodka ${ }^{25}$.

W Polsce problem małżeństw osób z upośledzeniem umysłowym nie jest rozwiązany. Niektóre osoby niepełnosprawne intelektualnie żyją w nieformalnych związkach. Niekiedy mają dzieci, którymi opiekują się najczęściej matki przy pomocy babci. W małżeństwie osoby te nie przywiązują dużej wagi do współżycia płciowego. Koncentrują się raczej na czułości i na byciu z drugim człowiekiem. Jak zauważa Kazimiera Nowak-Lipińska, małżeństwo jest dla nich próbą zdarcia z siebie etykiety osoby upośledzonej. „Małżeństwo jawi się im jako ratunek dla ich człowieczeństwa zarówno we własnych oczach, jak i w odbiorze społecznym. W zainteresowanie małżeństwem wpisany jest protest przeciwko samotności i głęboka potrzeba bliskości drugiego człowieka”26.

\section{Przyszlość}

Osiaggnięcie pełnoletności przez osoby z upośledzeniem umysłowym nie oznacza więc końca trosk rodziców. Część osób z lekkim upośledzeniem umysłowym zakłada rodziny i podejmuje pracę. Trudniejsza jest sytuacja rodzin posiadających dzieci z umiarkowanym, znacznym czy głębokim upośledzeniem umysłowym, a więc tych, które nie usamodzielniły się i pozostają pod opieką rodziców. Starzejący się rodzice martwią się o losy swoich dorosłych dzieci, a zwłaszcza co się z nimi stanie w czasie ich ciężkiej choroby czy śmierci. Ważkim problemem jest przyszłość osób niepełnosprawnych intelektualnie po utracie rodziców. Zasadniczo trafiają one do domów opieki społecznej. W Polsce jest ponad 600 domów pomocy społecznej, w tym ponad 500, w których mieszkają osoby niepełnosprawne z racji upośledzenia, kalectwa, choroby lub z innych przyczyn sprawiających, że nie mogą żyć w rodzinach ani podjąć samodzielne-

${ }^{24}$ Podaję za K. Nowak-Lipińska, O kontrowersjach wokót matżeństw osób głębiej upośledzonych umystowo, w: B. Czech (red.), Matżeństwo w prawie świeckim i w prawie kanonicznym, Katowice 1996, s. 529-530.

${ }^{25}$ M. Hentszel, Das Sexaulwissen geistig behinderten Erwachsenen und ihre Einstellung zur Sexualität, Giessen 1984, s. 26.

${ }^{26}$ K. Nowak-Lipińska, dz. cyt., s. 535. 
go życia ${ }^{27}$. Domy te podlegają w ostatnich latach przemianom. Odchodzi się od wzorowanej na szpitalu, organizacji życia codziennego przez obsługiwanie podopiecznych i zaspokajanie podstawowych potrzeb bytowych do warunków życia w zwykłych domach ${ }^{28}$.

Na szczególną uwagę zasługuje wspólnota „Arka” założona w 1964 r. przez Jeana Vaniera. We wspólnocie tej osoby pełnosprawne starają się prowadzić codzienne życie razem z osobami z upośledzeniem umysłowym. Zanim coś dla tych osób zrobią, chcą przede wszystkim z nimi przebywać. Poprzez życie wspólnotowe i miłość, której doświadczają osoby niepełnosprawne intelektualnie, stopniowo zaczynają odkrywać, że i oni są ludźmi wartościowymi a nie żyjącymi na marginesie społeczeństwa ${ }^{29}$. W Polsce powstały także cztery domy na wzór wspólnoty „Arka”. Oparta na tych ideałach jest także wspólnota „Wiara i Światło” działająca przy wielu parafiach. Obecnie istnieje około 180 takich wspólnot.

Starając się zaradzić problemom, związanym z przyszłością osób niepełnosprawnych, tworzy się domy dla osób z upośledzeniem umysłowym. Jednak liczba tego typu placówek jest niewystarczająca. Jednym z takich domów jest Schronisko dla osób Niepełnosprawnych w Radwanowicach, działające od września 1989 r. i będące placówką macierzystą Fundacji Brata Alberta w Krakowie. Celem tej placówki jest opieka nad osobami z umiarkowanym lub znacznym upośledzeniem umysłowym, będącymi sierotami społecznymi lub naturalnymi. Praca wychowawcza w Schronisku prowadzona jest w oparciu o małe 8-10 osobowe grupy, które mają zastąpić osobom niepełnosprawnym ich utracone rodziny. Fundacja prowadzi także kilkanaście Warsztatów Terapii Zajęciowej, domy dziennego pobytu i ośrodki adaptacyjne.

Pojawia się także problem eutanazji osób niepełnosprawnych i ortotanazji, czyli zezwalania na śmierć przez brak podjęcia leczenia ${ }^{30}$. W Polsce problem ten nie jest tak nabrzmiały jak w Europie Zachodniej, ale zagrożenie to istnieje. Należy bać się społeczeństwa wysterylizowanego z cierpienia, chorób, śmierci, w którym istnieje rywalizacja i dążenie do osiągnięcia najwyższej jakości, w których nie ma po prostu miejsca na ludzką słabość. „Za pośrednictwem tych osób możemy dotknąć jądra człowieczeństwa, które nie zależy od tego, jak funkcjonuje nasze ciało i nasz umysł"'31.

${ }^{27}$ E. Tarkowska, Ludzie w instytucji totalnej. Przypadek domów pomocy społecznej w Polsce, w: A. Gustavsson i E. Zakrzewska-Manterys (red.), dz. cyt., s. 123.

${ }^{28}$ Tamże, s. 123-134.

${ }^{29}$ J. Vanier, Wspólnota miejscem radości i przebaczenia, tłum.. M. Żurowska, Warszawa 1991, s. 17.

${ }^{30}$ A. Wojciechowski, Odrzucony niepetnosprawny, odrzucona rodzina, w: M. Chodkowska (red.) Dziecko niepetnosprawne w rodzinie, Lublin 1995, s. 190.

${ }^{31}$ A. Sobolewska, dz. cyt., s. 289. 


\section{Podsumowanie}

Obecność dziecka niepełnosprawnego intelektualnie stawia rodziców w niezwykle trudnej i specyficznej sytuacji przez całe ich życie. Przeżywają oni problemy o różnym charakterze. Ich sytuację poprawiłaby pomoc osób drugich. Rodzice oczekuja pomocy w zaakceptowaniu upośledzenia swojego dziecka zarówno przez nich, jak i przez otoczenie. Potrzebuja wiedzy o stanie dziecka i ukierunkowaniu ich pracy. Poszukują oni dla swoich dzieci specjalistycznych placówek opiekuńczych, edukacyjnych czy rewalidacyjnych. Ogromna liczba problemów rodziców wiąże się z poszukiwaniem i nieznalezieniem miejsc, w których zaopiekowano by się ich dziećmi w sposób kompetentny. Bardzo ważna jest grupa wsparcia, dająca rodzicom poczucie więzi, ale i oparcia w ich trudnej sytuacji. Rodzice potrzebują przede wszystkim poczucia bezpieczeństwa i pewności, że w razie ich choroby czy śmierci będzie miał kto zaopiekować się ich niepełnosprawnym intelektualnie dzieckiem.

\section{Problems of families of children intellectually disabled (Summary)}

Parents of intellectually disabled children struggle with many problems. They face trauma when the information is given by the doctor. There are several periods in parent's emotions: shock, emotional crisis, and constructive adaptation to the situation. Parents of mentally ill children also face social isolation and stigmatisation. An important event in their lives is the start of their children's education. Children start it in a special schools, other in normal schools and later they continue it in special technical schools or educational centers. The growing-up time of intellectually disabled children is the time of many parent's indecisions connected with their children's further education. Some of them take part in Therapy Classes, join communities like "Arka" or "Wiara i światło". Reaching adulthood by intellectually disabled does not mean the end of parental care. Some of the disabled have their own families and start to work. Much more difficult is situation of those families, whose children are not independent and still need parental help. After parent's death, people intellectually disabled usually go to residential institutions for the care of mentally handicapped children because there aren't enough alternative places for people mentally ill. That is why the presence of an intellectually disabled child puts parents in a very difficult and specific situation during all their lives. 